\title{
GOSPODARCZO-FINANSOWE ASPEKTY DZIAŁALNOŚCI SAMORZĄDU TERYTORIALNEGO W RAMACH INWESTYCJI CENTRALNEGO OKRĘGU PRZEMYSŁOWEGO (1936-1939)
}

Od pierwszych lat dwudziestolecia międzywojennego dostrzegano potencjalne korzyści z lokowania ważnych dla obronności kraju przedsiębiorstw przemysłowych w tzw. trójkącie bezpieczeństwa. Obejmował on głównie terytorium Staropolskiego Okręgu Przemysłowego. Warunkiem powodzenia programów inwestycyjnych była rozbudowa infrastruktury energetycznej i komunikacyjnej. To zaś stworzyło przesłanki do rozwoju nie tylko przemysłu wojennego, ale i produkcji cywilnej ${ }^{1}$. Po okresie Wielkiego Kryzysu oraz w sytuacji wzrastającego niebezpieczeństwa międzynarodowego pojawiły się przesłanki do koordynacji poczynań inwestycyjnych w postaci jednolitego planu. Czteroletni plan inwestycyjny z 5 II $1937 \mathrm{r}$. stanowił ostateczna wersję planowanej budowy Centralnego Okręgu Przemysłowego (po uprzedniej wersji tego planu z 10 VI 1936 r.) $)^{2}$. Obejmował on oddalone od granic państwowych obszary 44 powiatów, stanowiących łącznik woj.: kieleckiego, lubelskiego, krakowskiego i lwowskiego. Obszar, w którym lokowano najważniejsze inwestycje, znajdował się w dorzeczu Wisły, Sanu i Dunajca. Wojskowe aspekty inwestycji opierały się na sześcioletnim planie inwestycyjnym, który został utworzony przez Sztab Główny Wojska Polskiego na początku 1936 r. ${ }^{3}$ W tymże roku z ini-

${ }^{1}$ J. Gołębiowski, Podstawa „trójkata bezpieczeństwa”, „Przemiany” 17, 1986, nr 9 (189), s. 1.

${ }^{2}$ M.M. Drozdowski, Polityka gospodarcza rzadu polskiego 1936-1939, Warszawa 1963, s. 140.

${ }^{3}$ Tenże, Geneza i rozwój Centralnego Okręgu Przemystowego, w: Najnowsze dzieje Polski. Materiaty i studia z okresu 1914-1939, t. 2, Warszawa 1959, s. 55; R. Tomaszewski, Militarno-obronne aspekty koncepcji gospodarczych Eugeniusza Kwiatkowskiego do 1939 roku, „Rocznik Koszaliński” 2001, nr 29, s. 38. 
cjatywy Eugeniusza Kwiatkowskiego - ówczesnego ministra skarbu w rządzie Felicjana Sławoja Składkowskiego - utworzono Biuro Planowania Krajowego. Funkcjonowało ono przy gabinecie Eugeniusza Kwiatkowskiego i koordynować miało realizację czteroletniego planu inwestycyjnego ${ }^{4}$. W ramach realizacji COP funkcjonowały również Komisje Regionalnych Planów Zabudowania, wraz z określonymi okręgami planów zabudowania. W przypadku COP były to: krakowski, lwowski, radomsko-kielecki, lubelski oraz oddzielnie wydzielony okręg dla $\mathrm{COP}^{5}$. Pierwsze prace zwiazane $\mathrm{z}$ realizacja planu inwestycyjnego rozpoczęto w lipcu $1936 \mathrm{r}^{6}{ }^{6} \mathrm{~W}$ ramach tego planu priorytet wśród grupy zagadnień infrastrukturalnych stanowiły energetyczne: budowa elektrowni, linii wysokiego napięcia, sieci gazociagów. Istniały na terenie oraz w pobliżu COP złoża gazu. Planowano wykorzystać siły wodne Wisły, Sanu i Dunajca poprzez ich regulację, budowę tam oraz elektrowni wodnych. Regulacja koryt rzek miała również umożliwić rozwój żeglugi śródlądowej. Planowano budowę nowych i odnowę istniejących dróg bitych, linii kolejowych, a także węzłów komunikacyjnych. Planowano również rozwijać różnego rodzaju inwestycje radio-telekomunikacyjne. Najważniejsze nakłady wiązały się z rozbudową przemysłu i tworzeniem zakładów przemysłowych o określonej branży wytwórczości, ze szczególnym uwzględnieniem zagadnień militarnych. Zamierzano zorganizować budowę mieszkań dla robotników. Planowano modernizację miast pod względem infrastruktury wodociagowej, kanalizacyjnej, rozmieszczenia sieci elektrycznych oraz innych inwestycji zwiazanych $\mathrm{z}$ infrastruktura komunalna ${ }^{7}$. Wymienione $\mathrm{w}$ ostatnim zdaniu zagadnienia inwestycyjne stanowiły część kompetencji i działalności samorządu terytorialnego. W tym artykule to właśnie działalność samorządu terytorialnego na terenie COP będzie stanowić główny punkt rozważań autora.

${ }^{4}$ I. Kostrowicka, Rozwój planowania przestrzennego $w$ Polsce międzywojennej, w: Badania nad historia gospodarczo-społeczna $w$ Polsce (problemy i metody), red. J. Topolski i in., Warszawa-Poznań 1978, s. 224-225.

${ }^{5}$ A. Jackowski, Instytut Geograficzny Uniwersytetu Jagiellońskiego i poczatki planowania przestrzennego w Krakowie (do 1945 r.), w: Gospodarka i przestrzeń. Prace dedykowane Profesor Danucie Ptaszyckiej-Jackowskiej, red. B. Domański, W. Kurek, Kraków 2009, s. 129.

${ }^{6}$ M.M. Drozdowski, Polityka gospodarcza ostatniego gabinetu II Rzeczypospolitej, PH, t. 52, 1961, z. 1, s. 65.

${ }^{7}$ W. Samecki, Centralny Okręg Przemystowy. Wstęna faza uprzemystowienia Polski, Wrocław 1998, s. 255-268. 


\section{Rola samorządu terytorialnego w życiu gospodarczym Polski w okresie rządów sanacji (1926-1939)}

Obóz rządzący po 1926 r. zaadaptował dla swych potrzeb ideę samorządu terytorialnego wypracowaną przez Jerzego Panejkę, której fundamentem było postrzeganie samorządu jako ważnego elementu struktury państwa. Zadaniem samorządu terytorialnego w takim ujęciu było wykonywanie części zadań administracji państwowej oraz współdziałanie w realizacji celów o znaczeniu ogólnopaństwowych. Według państwowej teorii samorządu nie istniała żadna różnica między administracją samorządową a rządowa, obie bowiem współtworzyły administrację państwowa ${ }^{8}$. W związku z tym też działalność samorządu terytorialnego z przyczyn oczywistych musiała być w większym stopniu skoordynowana z państwową polityka gospodarcza. Jak słusznie podkreśla Waldemar Paruch: „Piłsudczykowskie myślenie o samorządzie było oparte na przekonaniu, że jest on struktura przymusowa dla obywateli oraz działająca w imieniu i dla jego dobra w wymiarze lokalnym"9. Przedstawienie powyższych sugestii jest ważne dla zrozumienia istoty i roli funkcjonowania samorzadu terytorialnego $\mathrm{w}$ ramach inwestycji COP. Był on bowiem inwestycja prowadzona w przeważajacym stopniu w ramach działalności państwa. Tak silne, zarówno ideologiczne, jak i organizacyjne związanie samorządu terytorialnego z państwem nie mogło nie mieć wpływu na zrzucenie nań wysokiego stopnia odpowiedzialności gospodarczo-finansowej w ramach inwestycji COP, obejmującej przecież 44 powiaty z czterech województw.

\section{Problematyka samorządu terytorialnego w Centralnym Okręgu Przemysłowym}

Zainteresowanie autora kwestią działalności samorządu terytorialnego na terenie COP wzbudziło odnalezienie w przedwojennych czasopismach samorządowych (i nie tylko) wielu artykułów poświęconych właśnie samorządowym aspektom rozwoju COP oraz funkcjonowania gospodarki komunalnej z drugiej połowy lat trzydziestych. Wymie-

${ }^{8}$ A. Bosiacki, U podstaw doktryny samorzadu terytorialnego II Rzeczypospolitej. Naturalistyczna $i$ państwowa teoria samorzadu terytorialnego $i$ jej geneza $w$ europejskiej myśli prawnej, CPH, t. 57, 2005, z. 2, s. 336-338.

${ }^{9}$ W. Paruch, Samorzady a autorytaryzmie. Piłsudczykowska koncepcja samorzadności (1926-1939), w: Samorzad w polskiej myśli politycznej XX wieku, red. G. Radomski, Toruń 2006, s. 158. 
nię tytuły tylko niektórych czasopism: „Samorząd Miejski”, „Samorząd Terytorialny”, „Przegląd Samorządowy”, „Samorząd”, „C.O.P.”, „Gazeta Administracji i Policji Państwowej”" Większość artykułów

${ }^{10}$ Najważniejsze artykuły to: w czasopiśmie „C.O.P.”: Rozwój Rzeszowa w ostatnich dwu latach (1938, nr 20, s. 4); A. Musielski, Wczoraj, dziś i jutro miasta Sandomierza (1938, nr 20, s. 5); C.O.P.-owa Komisja Zwiazku miast (1938, nr 7, s. 6); Cz.G., Budowa szkót w powiecie puławskim (1938, nr 17, s. 3); Inwestycje gospodarczo-społeczne w pow. mieleckim (1939, nr 8, s. 8); Inwestycje w pow. bitgorajskim i puławskim (1938, nr 23, s. 6); Inwestycje w powiecie tarnobrzeskim (1939, $\mathrm{nr} 4$, s. 6); J. Czesławski, Rozwój Komunalnej Kasy w pow. opatowskim (1939, nr 11, s. 6); J.N., O wspótpracę K.K.O. Polski Zachodniej z K.K.O. Centralnego Okręu (1938, nr 20, s. 4); K.K.O. Rzeszów (1938, nr 18, s. 8); K.K.O. Sandomierz (1938, nr 18, s. 8); k.1., Obniżenie cen artykułów pierwszej potrzeby w Mielcu (1939, nr 12, s. 7); Lublin na nowych drogach. Rozmowa z prezydentem miasta (1939, nr 29, s. 4); M.L., Samorzqd „odpolityczniony” (1938, nr 12, s. 3); M. Obertyński, W Dębicy szaleje drożyzna (1938, nr 10, s. 5); O szkoty powszechne w C.O.P. (1938, nr 22, s. 6); O ulice w miastach C.O.P. (1938, nr 5, s. 5); O wspótpracę samorzadów miejskich ze społeczeństwem (1939, nr 13, s. 3); Plan inwestycyjny pow. sandomierskiego (1939, nr 18, s. 6); Podstawowy warunek rozwoju. O inwestycje na terenie miast C.O.P. (1939, $\mathrm{nr} 12$, s. 3); Roboty miejskie w C.O.P. (1938, nr 7, s. 6); Rola Komunalnych Kas Oszczędności w życiu gospodarczym C.O.P. (1939, $\mathrm{nr}$ 30, s. 20); S. Piotrowski, Rozbudowa przemystu przyczynia sie do rozwoju miast (1938, nr 21, s. 8-9); Samorzqd miejski i przedsiębiorczość prywatna (1939, nr 2, s. 1); Szpitalnictwo w C.O.P. (1938, nr 7, s. 6); T. Kutrzeba, Mielec w walce z drożyzna (1939, $\mathrm{nr} 12$, s. 5); tenże, Rozbudowa szkolnictwa (1938, nr 19, s. 10); W sprawie budowy szkót powszechnych niedomagania i trudności (1938, nr 20, s. 7); Ważne dla zarzqdów miast (1938, nr 15, s. 2); Wydatki miast C.O.P. (1939, nr 6, s. 8); Zagadnienia gospodarcze w C.O.P. na terenie pow. kolbuszowskiego, krośnieńskiego, tańcuckiego, niżańskiego, przeworskiego, rzeszowskiego i tarnobrzeskiego (1939, $\mathrm{nr} 25-26$, s. 4); Zagadnienia gospodarcze $w$ C.O.P. na terenie pow. kolbuszowskiego, krośnieńskiego, tańcuckiego, niżańskiego, przeworskiego, rzeszowskiego i tarnobrzeskiego (1939, nr 27-28, s. 5); Zamość dzisiejszy (1939, nr 29, s. 7); Zjazd przedstawicieli miast C.O.P. (1938, nr 27, s. 6); w czasopiśmie „C.O.P.” w większości numerów znajduje się również kronika poświęcona poszczególnym miastom; w czasopiśmie „Samorząd”: M. Klonowski, Rola komunalnych kas oszczędności (Rozważania Dzień Oszczędności) (1938, nr 44, s. 687-699); F. Branny, Zadania zwiazków samorzadowych w Centralnym Okregu Przemysłowym (1937, nr 46, s. 719-721), Sprawa Centr. Okregu Przemystowego na Radzie Powiatowej w Sandomierzu (woj. kieleckie) (1937, nr 24, s. 361); S. Malanowicz, Zagadnienie zdrowia publicznego w C.O.P. (1938, nr 22, s. 363-365); K. Romaniuk, Centralny Okręg Przemysłowy z perspektywy samorzqdowej (1937, nr 47, s. 735-738); w czasopiśmie „Gazeta Administracji i Policji Państwowej”: A. Kuncewicz, Planowanie regionalne (1939, nr 7, s. 440-444); Zagadnienia zdrowotne Centralnego Okregu Przemystowego (1938, nr 8, s. 540-541); L. Starzyński, Sytuacja finansowa samorzadu terytorialnego $w$ świetle danych statystycznych (1939, $\mathrm{nr} 6$, s. 322-333); w czasopiśmie „Przegląd Samorządowy”: Inwestycje Pow. Zw. Samorzadowego w Mielcu w zwiazku z budowa C.O.P. (1939, nr 2, s. 13); J. Przetocki, Problem inwestycji $w$ Centralnym Okregu Przemystowym (1938, nr 1-4); K. Chmiel, Sytuacja miasta Mielca $w$ zwiazku z budowa C.O.P. (1939, nr 2, s. 8-10); L. Osiecki, Gospodarcza rola 
z wyżej wymienionych czasopism, przywołanych w przypisie 10, stanowiła dla autora bardzo ważny motyw i istotna inspirację dla zajęcia się tym tematem. Dla podjęcia badań nad zagadnieniem gospodarczej działalności samorządu terytorialnego w COP ważną rolę pełnią opracowania tużpowojenne oraz współczesne, dotyczace samorządu terytorialnego w II $\mathrm{RP}^{11}$. Istotne okazały się również materiały źródłowe z zespołu: Związek Powiatów Rzeczypospolitej znajdującego się w Archiwum Akt Nowych w Warszawie. W mniejszym

samorzadu w Polsce Odrodzonej (1938, nr 12, s. 1-3); Prace inwestycyjne C.O.P. - Dębicy (1939, nr 4, s. 9-10); Uzgadnianie programu inwestycyj samorzadowych w C.O.P. (1938, nr 5, s. 11); W. Kabaciński, Dajmy szkołom powszechnym urzadzenia szkolne i pomoce naukowe (1938, nr 12, s. 3-4); w czasopiśmie „Samorząd Miejski”: Akcja kredytowa K.K.O. na terenie C.O.P. (1938, nr 13, s. 938); Konferencja miast z obszaru C.O.P. (1938, nr 9, s. 695-697); M. Porowski, Wymowa liczb (1939, nr 2, s. 79-89); Miasta Centralnego Okregu Przemystowego (1938, nr 11-12, s. 833-834); Nadzór na cenami w C.O.P. (1938 nr 16-17, s. 1121); Najpilniejsze potrzeby inwestycyjne miast COP (1939, nr 3, s. 256-268); Referat St. Zbrożyny pt. Zagadnienia gospodarcze miast na obszarze Centralnego Okregu Przemystowego (1938, nr 10, s. 728-736); S. Bonarek, S. Stęplewski, Sytuacja finansowa i gospodarcza miast regionu „C”(Centralnego Okręgu Przemystowego) (1938, z. 3-4, s. 221-248); S. Dębowski, Sytuacja miast Centralnego Okregu Przemysłowego na terenie województw krakowskiego i lwowskiego (regionu C) (1938, nr 14-15, s. 951-963); S. Stęplewski, Wydatki zwyczajne miast w r. 1937/38 $w$ przeliczeniu na jednego mieszkańca (1939, nr 2, s. 90-110); Zagadnienia gospodarcze miast na obszarze Centralnego Okregu Przemystowego (1938, nr 10, s. 723-728); Zagadnienia zdrowotne w okręgu (C) Centralnego Okregu Przemysłowego (1938, nr 9, s. 712-713); w czasopiśmie „Samorząd Terytorialny”: M. Jaroszyński, Rozważania wstepne na temat reformy finansów komunalnych (1937, nr 3-4, s. 1-16); Sprawy samorzadowe w Centralnym Okregu Przemystowym (1938, z. 1-2, s. 167-168).

${ }^{11}$ R. Ciałkowski, Gospodarka budżetowa organów lokalnych w Polsce (1918-1990), Katowice 1991; tenże, System prawno budżetowy organów lokalnych w Polsce (1918-1990), Katowice 1990; M. Grzybowska, Decentralizacja i samorzad w II Rzeczypospolitej (aspekty ustrojowo-polityczne), Kraków 2003; M. Klimek, Samorzad miast II Rzeczypospolitej. Publiczna debata i rozwiazania ustrojowe, Lublin 2006; K. Niemski, Gospodarka finansowa samorzadu terytorialnego i kredyt komunalny $w$ Polsce, Łódź 1946; P. Ruczkowski, Komunalne Kasy Oszczędności w Drugiej Rzeczypospolitej. Ustrój prawny i działalność, Sandomierz 2010; S. Staśko, Wielkie miasto przemystowo-handlowe, Katowice 1938; R. Szwed, Centralne Zwiazki Samorzadowe w Polsce (1917-2003), Częstochowa 2003; A. Wiktorowska, Zwiazki komunalne w Polsce przedwojennej. Nadzór w systemie samorzqdu terytorialnego (analiza historyczno-prawna), Warszawa 1990; M.M. Wójcicki, System polityczno-prawny samorzqdu terytorialnego $w$ II RP. Podstawy organizacyjno-prawne samorzadów terytorialnych $i$ w mieście stołecznym Warszawie w latach 1918-1939. Studium polityczno-prawne, Katowice 2008; A.W. Zawadzki, Finanse samorzadu terytorialnego $w$ latach 1918-1939, Warszawa 1971; S.M. Zawadzki, Planowanie regionalne w Polsce 1928-1939, w: Studia z zakresu planowania regionalnego $i$ teorii gospodarki przestrzennej, „Biuletyn. Komitet Przestrzennego Zagospodarowania Kraju Polskiej Akademii Nauk" 1971, z. 62, s. 9-55. 
stopniu zostały wykorzystane również materiały z Centralnego Archiwum Wojskowego w Warszawie, Archiwum Państwowego w Rzeszowie oraz Archiwum Państwowego w Lublinie, które zwróciły uwage autora $\mathrm{w}$ trakcie kwerendy. Materiały archiwalne zostaną omówione poniżej. Autor odnalazł jedynie sześć pozycji z historiografii współczesnej, w których poruszana jest problematyka samorzadu terytorialnego w COP w aspekcie gospodarczym ${ }^{12}$. Ustrój samorządu terytorialnego w II RP wyszczególniał: gromady i gminy wiejskie, samorząd miejski, powiatowy oraz wojewódzki, a także związki międzykomunalne, w skład których wchodzić mogły gminy wiejskie i miejskie oraz powiatowe i wojewódzkie związki samorządowe ${ }^{13}$. Przedstawiona w artykule problematyka samorządu terytorialnego w COP nie zostanie zaprezentowana według podziału struktury samorządu, lecz jego szczegółowych funkcji gospodarczo-finansowych.

\section{Gospodarcze aspekty działalności samorządu terytorialnego na terenie $\mathrm{COP}$}

Samorząd terytorialny w II RP miał nałożone przez prawo ściśle określone zadania w ramach koordynacji funkcjonowania gospodarki lokalnej oraz zaspokajania potrzeb lokalnych społeczeństw. Przedstawiciele

${ }^{12}$ Zob. M.M. Drozdowski, Marceli Porowski. Prezydent powstańczej Warszawy, Warszawa 2010; R. Szwed, Samorzqdowa Rzeczpospolita 1938-1939. Wybór rozpraw $i$ artykułów, Częstochowa 2000; W. Kozyra, Rola struktur administracji państwowej $w$ realiach myśli politycznej sanacji w latach 1926-1939, w: Wizje i realia. Studia nad realizacja polskiej myśli politycznej XX wieku, red. W. Paruch, K. Trembicka, Lublin 2002, s. 141-156; R. Tłuczek, Samorzad terytorialny gmin miejskich i wiejskich powiatu kolbuszewskiego, tańcuckiego, mieleckiego i rzeszowskiego w latach 1918-1939, Rzeszów 1997, mps rozprawy doktorskiej przyg. pod kier. prof. dr. hab. Tomasza Opasa, Wydział Prawa i Administracji UMCS, filia w Rzeszowie; J. Petrus, Organizacja i funkcjonowanie władz terenowych administracji ogólnej na Rzeszowszczyźnie w okresie od wyzwolenia do wejścia $w$ życie ustawy o terenowych organach jednolitej władzy państwowej (sierpień 1944 - marzec 1950), t. 1, Lublin 1977, mps rozprawy doktorskiej przyg. pod kier. prof. dr. hab. Władysława Ćwika na Uniwersytecie Marii Curie-Skłodowskiej w Lublinie; J. Główka, Komisja Regionalnego Planu Zabudowania Okręgu Kielecko-Radomskiego i modernizacja przemystu $w$ Zagtębiu Staropolskim $w$ latach 1937-1939, w: Między Wista a Pilica. Studia i materiaty historyczne" t. 3, red. B. Wojciechowska, L. Michalska-Bracha, Kielce 2001, s. 243-260.

${ }^{13}$ Szczegółowe zasady ustrojowe samorządu terytorialnego w II RP zob. K.W. Kumaniecki, Ustrój samorzqdu terytorialnego, w: K.W. Kumaniecki, J.S. Landgrod, S. Wachholz, Zarys ustroju, postepowania i prawa administracyjnego $w$ Polsce, Kraków-Warszawa 1939, s. 37-95. 
samorządu terytorialnego wchodzili w skład wojewódzkich rad Funduszu Pracy. W ramach jego działalności mieściło się m.in. opracowywanie projektów finansowania robót publicznych i zatrudnianie w nich bezrobotnych ${ }^{14}$. Związki samorządowe miały również obowiązek świadczenia opieki społecznej ${ }^{15}$. Wraz z administracją rządową administracja samorządowa sprawowała pieczę nad służbą zdrowia publicznego i prowadziła publiczne placówki zdrowia ${ }^{16}$. Do organizacji planów zabudowania osiedli, służących do przeprowadzenia regulacji i prawidłowego zabudowania terenów, zobowiązane były m.in. zarządy miejskie i wydziały powiatowe. Regionalne plany zabudowania organizowały komisje, w skład których wchodzili m.in. delegaci samorządu terytorialnego ${ }^{17}$. Związki samorządu terytorialnego zobligowane były do współudziału $\mathrm{w}$ organizacji inwestycji rolnych, m.in. melioracji samoistnych (melioracje dokonywane $\mathrm{w}$ zwiazku z przebudową ustroju rolnego koordynowały władze administracji ogólnej) ${ }^{18}$. Wśród zadań samorządu terytorialnego znajdowały się również sprawy związane ze współudziałem w prowadzeniu gospodarki hodowlanej i popieraniu rolnictwa ${ }^{19}$. Samorząd terytorialny odpowiadał za utrzymywanie i zakładanie publicznych szkół powszechnych ${ }^{20}$. Samorząd gminny i miejski zobligowany był również do zakładania publicznych szkół zawodowych dokształcających ${ }^{21}$. $\mathrm{W}$ ramach gospodarki samorządu terytorialnego funkcjonowały przedsiębiorstwa komunalne i inne gałęzie gospodarki komunalnej: gazownie, tramwaje, elektrownie, wodociagi, kanalizacje, rzeźnie, targowice zwierzęce, chłodnie, fabryki lodu, zakłady czyszczenia ulic, cegielnie, betoniarnie, kamieniołomy, tartaki, a także gospodarstwa rolne, leśne i rybne, które stanowiły oddzielne jednostki gospodarcze, itd. ${ }^{22}$ Do gospodarczych zadań samorządu terytorialnego należała budowa i przebudowa dróg wojewódzkich, powiatowych i gminnych ${ }^{23}$. Ważna dziedzina, którą mieli prawo kontrolować prezydenci miast wydzielonych

\footnotetext{
${ }^{14}$ J.S. Langrod, Praca i ubezpieczenia społeczne, w: tamże, s. 414-416.

15 Tamże, s. 441.

${ }^{16}$ S. Wachholz, Zdrowie publiczne, w: K.W. Kumaniecki, J.S. Landgrod, S. Wachholz, Zarys ustroju..., s. 473, 486-488.

${ }^{17}$ K.W. Kumaniecki, Budownictwo i zabudowanie osiedli, w: tamże, s. 494-499.

${ }^{18}$ J.S. Langrod, Rolnictwo i leśnictwo, w: tamże, s. 584-585.

${ }^{19}$ Tamże, s. 587-600.

${ }^{20}$ S. Wachholz, Szkolnictwo, w: K.W. Kumaniecki, J.S. Landgrod, S. Wachholz, Zarys ustroju..., s. 368.

${ }^{21}$ Tamże, s. 272.

${ }^{22}$ K.W. Kumaniecki, Przemyst $i$ handel, w: K.W. Kumaniecki, J.S. Landgrod, S. Wachholz, Zarys ustroju..., s. 650-651.

${ }^{23}$ S. Wachholz, Komunikacje, w: tamże, s. 708.
} 
oraz starostowie na podstawie uprawnień przekazywanych przez wojewodów, była kwestia kontroli cen na rynkach lokalnych ${ }^{24}$. Związki samorządowe organizowały także dla społeczeństwa kredyt komunalny ${ }^{25}$. Kwestia funkcjonowania gospodarki samorzadowej na terenie COP omówiona zostanie na wybranych przykładach.

COP stanowił terytorium wzmożonej działalności inwestycyjnej, zarówno państwowej, jak i samorządowej. Związki samorządowe na terenie COP musiały dostosować swoją politykę do nowej rzeczywistości gospodarczej. Dynamiczna realizacja inwestycji na terenie COP powodowała wzrost cen gruntów ${ }^{26}$. Nieutworzenie wcześniej zapasów gruntów przez związki samorządowe przeszkodziło w swobodnym dysponowaniu terenami pod zabudowę mieszkań i różnego rodzaju obiektów użyteczności publicznej (ośrodki zdrowia, targowiska, ośrodki pomocy społecznej itp.). Z powodu niewielkich możliwości finansowych szczególnym problemem dla związków samorządowych była budowa dróg lokalnych. Źródło siły roboczej przy robotach publicznych stanowić mieli niewykwalifikowani bezrobotni oraz małorolni. Zmiana struktury gospodarczej pociagała za sobą również konieczność intensyfikacji akcji popierania rolnictwa. Poza tym cały szereg innych problemów gospodarki lokalnej miał spowodować wzmożenie gospodarczej działalności związków samorządowych COP. Związki samorządowe musiały również poznać państwowy plan gospodarczy w celu dostosowania do tego planu własnej polityki. Konieczne było przedsięwzięcie współpracy przedstawicieli samorządu terytorialnego z przedstawicielami władz państwowych, samorządów gospodarczych itp. ${ }^{27}$

Związki samorządowe wykazywały faktyczne zainteresowanie kwestiami inwestycji w COP. Zwiazek Miast Polskich 25 IV 1938 r. zorganizował konferencję miast z terenów COP. Wzięło w niej udział 28 miast z województw: krakowskiego, lwowskiego, kieleckiego i lwowskiego. Postulowano wówczas m.in. konieczność zwiększenia uwagi władz państwowych na gospodarcze problemy miast położonych w obrębie COP. Polegać to miało m.in. na zapewnieniu miastom środków na inwestycje miejskie, które stanowić miały element inwestycji państwowych; udzielaniu

${ }^{24}$ K.W. Kumaniecki, Przemyst $i$ handel..., s. 697-698.

${ }^{25}$ Zob. P. Ruczkowski, dz. cyt.; tenże, Gminne kasy wiejskie pożyczkowo-oszczędnościowe w Drugiej Rzeczypospolitej, Kielce 2009.

${ }^{26} \mathrm{Na}$ temat przyrostu wartości majątku na skutek wzrostu cen ziemi, renty gruntowej itp., m.in. na terenie COP, zob. J. Pic de Replogne, Kredyt a oddtużenie rolnictwa, Warszawa 1939, s. 32.

${ }^{27}$ F. Branny, dz. cyt., s. 719-721; S. Malanowicz, Warunki inwestowania, „Samorząd" 1937, nr 14, s. 209-211. 
dodatkowych kredytów na sporządzanie planów i pomiarów; pomocy państwa w polityce gruntowej; a także wspieraniu miast w polityce energetycznej. Zaplanowano również współpracę ze Związkiem Izb Przemysłowo-Handlowych w sprawach $\mathrm{COP}^{28}$. Utworzona została przy Związku Miast stała komisja miast COP ${ }^{29}$. 17 XII 1938 r. odbywała się w Warszawie konferencja zorganizowana przez Związek Miast Polskich. Uczestniczyli w niej przedstawiciele około 80 miast z terenów COP. Na konferencji omawiano stan gospodarczy tych miast. Przewodniczącym konferencji był ówczesny prezydent Lublina, Bolesław Stanisław Liszkowski. Podczas swojego przemówienia ocenił on stan gospodarczy miast COP jako zdecydowanie niekorzystny ${ }^{30}$. Zorganizowania konferencji podją się również Związek Powiatów. Pierwsza odbyła się 22 IV 1938 r. w Dębicy. Brały w niej udział cztery powiaty województwa krakowskiego. Natomiast druga zorganizowano 29 IV 1938 r. we Lwowie dla dziewięciu powiatów województwa lwowskiego. Na tychże konferencjach zostały omówione najważniejsze potrzeby powiatów w zakresie gospodarki samorządowej ${ }^{31}$. Projekt i realizacja COP stanowiła również ważną część dyskusji w lokalnych związkach samorządowych ${ }^{32}$.

Organizowanie inwestycji COP przyciagało bezrobotnych, chcących znaleźć pracę. Pochodzili oni nie tylko z terenów COP. Zdarzało się, że prowadzona ówcześnie prasowa propaganda przejaskrawiała możliwości rynku pracy. Potencjalni pracownicy - w szczególności niewykwalifikowani - przybywający na teren COP niejednokrotnie musieli doświadczać rozczarowania z powodu braku możliwości znalezienia pracy ${ }^{33}$. Musiało się to oczywiście negatywnie przekładać na gospodarczą działalność samorządów. W relacji pracownika samorządowego, która dotyczy wrażeń po podróży na terenach COP, czytamy: „Centralny Okręg Przemysłowy. Tyle się na ten temat pisze i mówi. [...] Samorządy na razie $\mathrm{z}$ tego niewiele maja. Wprawdzie zatrudniły bezrobotnych, lecz przybysze zagęszczają zaludnienie, siłą rzeczy wzmóc się musi opieka społeczna"34. Podobne spostrzeżenia znaleźć można w pracy Ryszarda Tłuczka: „Utworzenie COP-u, a co za tym idzie napływ ludności

${ }^{28}$ Sprawy samorzqdowe..., s. 167-168; Konferencja miast..., s. 695-697.

${ }^{29}$ R. Szwed, Samorzqdowa Rzeczpospolita..., s. 51.

${ }^{30}$ Zjazd przedstawicieli miast..., s. 6.

${ }^{31}$ Sprawy samorzqdowe..., s. 168.

${ }^{32}$ Sprawa Centr. Okręu Przemysłowego na Radzie Powiatowej w Sandomierzu..., s. 361; „Gazeta Administracji i Policji Państwowej” 1938, nr 6, s. 408-409.

${ }^{33}$ A.J. Kozłowski, A. Buszko, I.Z. Czaplicka-Kozłowska, Centralny Okreg Przemysłowy. Koncepcja i realizacja $w$ artykułach prasowych $z$ lat 1935-1939, Olsztyn 2010, s. 80 .

${ }^{34}$ „Pracownik Samorządowy” 1938, nr 7, s. 167. 
z zewnątrz, nie ułatwił samorządom w zakresie utrzymania porządku i bezpieczeństwa w miastach. Badania wykazały, że jesienia $1937 \mathrm{r}$. Rada Miejska w Rzeszowie poleciła Zarządowi Miejskiemu wnieść starania o zapewnienie bezpieczeństwa publicznego w porze nocnej, gdyż w ostatnich latach mnożą się kradzieże i włamania w zastraszający sposób. Pomimo wspomnianych niedociagnięć i trudności działalność samorządu miejskiego $\mathrm{w}$ sferze zapewnienia bezpieczeństwa i porządku publicznego ulegała stałej poprawie" ${ }^{35}$. Z powodu ograniczonej chłonności rynku pracy dla pracowników niewykwalifikowanych na terenie COP polecano, aby ruch robotników odbywał się wyłącznie przy współudziale biur pośrednictwa pracy ${ }^{36}$. Pojawiło się również zjawisko odpływu do COP wykwalifikowanych pracowników samorządowych z innych terenów, co było zapewne przejawem zwiększenia się zadań i obowiązków samorządu terytorialnego na terenie $\mathrm{COP}^{37}$.

Fakt napływu nowych grup pracowniczych i urzędniczych na tereny COP przyczynił się m.in. do zwiększenia popytu, co w następstwie spowodowało wzrost cen artykułów konsumpcyjnych, a także cen mieszkań. Ministerstwo Spraw Wewnętrznych poleciło władzom administracyjnym z terenów COP przeciwdziałać nadmiernym podwyżkom cen. Władze samorządowe często podejmowały w tej sprawie kontakty $\mathrm{z}$ wieloma organizacjami społecznymi i gospodarczymi ${ }^{38}$. Przykład wzrostu cen na terenie COP opisywany jest w relacji przedstawiajaccej kształtowanie się cen w Dębicy: „Nikt temu nie zapobiega. Nikt nie wgląda w te anormalne stosunki, które nawiedziły Dębicę, stwarzając z niej ośrodek nie tylko przemysłowy, ale i ośrodek drożyźniany. Ceny wyśrubowano w takim stosunku, że Kraków czy Katowice sa obecnie o wiele tańsze niż Dębica" ${ }^{39}$. Oceniano, że akcja regulacji cen na terenie COP w drugiej połowie 1938 r. przynosiła korzystne rezultaty ${ }^{40}$. Tego typu akcję przeprowadzono również na tym terenie w następnym roku. Na przykład w Mielcu po uchwałach Kongresu pracowników państwowych i samorządowych miasta Mielca zdecydowano się na uregulowanie

\footnotetext{
${ }^{35}$ R. Tłuczek, dz. cyt., s. 137; nt. kwestii bezpieczeństwa publicznego na terenie COP zob. R. Litwiński, Plany zabezpieczenia COP przez Policję Państwowa, w: Centralny Okręg Przemystowy. Infrastruktura. Produkcja. Procesy miastotwórcze. Materiaty $z$ konferencji naukowej odbytej $w$ Radomiu 19 grudnia 2005 roku, red. S. Piątkowski, Radom 2005, s. 17-27.

${ }^{36}$ Rynek pracy $w$ C.O.P., „C.O.P.” 1938, nr 27, s. 4.

37 „Samorzą" 1939, nr 9, s. 146.

${ }^{38}$ Nadzór nad cenami..., s. 1121.

${ }^{39}$ M. Obertyński, dz. cyt., s. 5.

${ }^{40}$ Nadzór nad cenami..., s. 1121.
} 
cen artykułów pierwszej potrzeby. Ustalone nowe ceny okazały się niższe od poprzednich ${ }^{41}$.

Rozbudowujący się dynamicznie na terenie COP przemysł, a w konsekwencji także handel i transport, powodowały pilna potrzebę budowy i rozbudowy dróg państwowych, a także samorządowych (gminne, miejskie, powiatowe i wojewódzkie) ${ }^{42}$. Część środków na drogowe inwestycje samorządowe pokrywane były m.in. z Państwowego Funduszu Drogowego ${ }^{43}$. Wedle przepisów prawa budowa i utrzymanie dróg państwowych leżała w kompetencji ministra komunikacji, który funkcje te wykonywał za pośrednictwem własnych organów lub związów samorządu terytorialnego. Budowa i utrzymanie odcinków dróg państwowych, wojewódzkich lub powiatowych, które przechodziły przez poszczególne miejscowości, mogło być przekazane tymże miejscowościom. $\mathrm{W}$ razie niewłaściwego bądź niedbałego wykonywania przez związi samorządowe tych obowiązków drogowych, mogły je przejąć związki samorządowe wyższego szczebla lub minister komunikacji, na rachunek odnośnych związków samorządowych. Fundusze związków samorządowych były zasilane środkami z zasobów Państwowego Funduszu Drogowego tylko w sytuacji, gdy została im przekazana administracja dróg państwowych ${ }^{44}$. W konsekwencji związki samorządu terytorialnego mogły odpowiadać za utrzymanie i budowę dróg bitych wszystkich kategorii ${ }^{45}$. Dokładne przedstawienie etapów budowy dróg samorzadowych przekroczyłoby możliwości objętościowe artykułu ${ }^{46}$. Tabela 1 przedstawia zmianę długości dróg samorządowych na terenie województw: kieleckiego, lubelskiego, krakowskiego i lwowskiego (w skład których wchodził COP) w latach 1924-1938.

\footnotetext{
${ }^{41}$ Obniżenie cen artykułów pierwszej potrzeby w Mielcu, „C.O.P.” 1939, nr 12, s. 7.

${ }^{42} \mathrm{~S}$. Rodowicz, Budowa, przebudowa $i$ utrzymanie dróg państwowych $i$ samorzadowych (w latach od 1 kwietnia 1928 r. do 1 kwietnia 1938 r.), „Samorząd” 1938, nr 17, s. 265.

${ }^{43}$ H.K. Hendrikson, Interwencja państwa $w$ zakresie komunikacji (komunikacja $w$ gospodarstwie społecznym Polski), Warszawa 1938, s. 49.

${ }^{44}$ S. Wachholz, Komunikacje..., s. 709-711.

${ }^{45}$ R. Pacanowska, Niedoceniony partner. Rola władz samorzadowych w przemianach społeczno-gospodarczych II RP, w: Między zacofaniem a modernizacja. Społeczno-gospodarcze problemy ziem polskich na przestrzeni wieków, red. E. Kościk, T. Głowiński, Wrocław 2009, s. 451.

${ }^{46}$ Szerzej nt. inwestycji drogowych na terenie COP zob. J. Gołębiowski, COP. Dzieje industrializacji $w$ rejonie bezpieczeństwa 1922-1939, Kraków 2000, s. 234-248.
} 
Tabela 1. Zmiana długości dróg państwowych i samorządowych z twardą nawierzchnią na terenie woj. kieleckiego, lubelskiego, krakowskiego i lwowskiego w latach 1924$-1938^{47}$

\begin{tabular}{|c|c|c|c|c|c|c|c|c|c|c|c|c|c|}
\hline \multirow{4}{*}{$\begin{array}{c}\text { Woje- } \\
\text { wództwo }\end{array}$} & \multicolumn{12}{|c|}{$\begin{array}{c}\text { Długość dróg państwowych i samorządowych o twardej na- } \\
\text { wierzchni przypadająca na } 100 \mathrm{~km}^{2}\end{array}$} & \multirow{4}{*}{\begin{tabular}{|c|}
$\begin{array}{c}\text { Po- } \\
\text { wierzch- } \\
\text { nia } \\
\text { woje- } \\
\text { wództw }\end{array}$ \\
km $^{2}$ \\
\end{tabular}} \\
\hline & \multicolumn{3}{|c|}{ państwowych } & \multicolumn{3}{|c|}{ wojewódzkich } & \multicolumn{3}{|c|}{ powiatowych } & \multicolumn{3}{|c|}{ gminnycl } & \\
\hline & 1924 & 19 & 1938 & 1924 & & 1938 & 1924 & $1935^{\mathrm{a}}$ & 1938 & 1928 & $36^{b}$ & 1 & \\
\hline & & & & & & km & $\mathrm{a} / \mathbf{k m}^{2}$ & & & & & & \\
\hline Kiele & 3,681 & 3, & 77 & 3 , & 4 , & 4,353 & 1,985 & 5 , & 5,369 & 0,004 & 881 & 5,268 & \\
\hline Lubelskie & 3,387 & 3,567 & 3,615 & 1,585 & 2,672 & 2,778 & 0,475 & 3,086 & 3,166 & & 2,162 & 2,77 & 31 \\
\hline & 5,955 & 6 , & 6,122 & 5,621 & 5,489 & 5,489 & 14,845 & 15,247 & 14,994 & 2,514 & 2,716 & 3 & \\
\hline wowskie & 4,052 & 4,210 & 4,224 & 3,584 & 3,689 & 3,693 & 5,410 & 9,089 & 9,036 & 1,422 & 1,482 & 2,042 & 28408 \\
\hline
\end{tabular}

${ }^{a}$ Dane sprzed podziału administracyjnego z 1 I 1938 r.;

b Dane za 1936 r. (stan na 1 I 1937 r.) - dane tymczasowe.

Z tabeli 1 można wysnuć następujące wnioski dotyczące dróg o twardej nawierzchni w województwach, które wchodziły w skład COP: w przypadku dróg państwowych w latach 1924-1935 najwięcej przybyło ich w woj. lubelskim, najmniej natomiast we lwowskim, a zmniejszyła się długość dróg w woj. kieleckim. W latach inwestycji COP (19351938) najwięcej dróg państwowych przybyło w woj. lubelskim, najmniej natomiast w krakowskim. W przypadku dróg wojewódzkich największa dynamiką budowy w latach 1924-1935 odznaczały się zdecydowanie woj. kieleckie i lubelskie, najmniejsza zaś lwowskie, a w krakowskim dróg ubyło. W latach 1935-1938 największą dynamiką wzrostu dróg odznaczyły się woj. kieleckie i lubelskie, natomiast w woj. krakowskim dróg nie przybyło. W przypadku dróg powiatowych w latach 1924-1935 największą dynamiką odznaczyło się woj. lwowskie, najmniejszą natomiast krakowskie, natomiast w latach 1935-1938 największa dynamiką odznaczyło się woj. kieleckie, ubyło natomiast dróg w woj. krakowskim i lwowskim. W przypadku dróg gminnych w latach 1924-1936 na podstawie dostępnych danych można stwierdzić, że największą dynamiką budowy nowych dróg o twardej nawierzchni odznaczyło się woj. kieleckie, co w tym przypadku spowodowane było niezwykle niskim stopniem długości dróg gminnych jeszcze w 1924 r. Najniższą

${ }^{47}$ S. Rodowicz, dz. cyt., s. 266; tenże, Budowa, przebudowa i utrzymanie dróg państwowych $i$ samorzadowych, „Samorząd” 1937, nr 27, s. 422; E Pol., Budowa dróg gminnych przy pomocy świadczeń w naturze, „Samorząd” 1937, nr 27, s. 427; E. Brzósko, Rozwój transportu w Polsce, Szczecin 1982, s. 138; „Mały Rocznik Statystyczny” 1939, s. 197. 
dynamiką odznaczyło się zaś woj. lwowskie. Natomiast w latach 19361938 najwięcej dróg gminnych wybudowano również w woj. kieleckim, a najmniej w woj. krakowskim. Na podstawie danych stwierdzić można również, że w 1938 r. największe zagęszczenie dróg państwowych, wojewódzkich i powiatowych o twardej nawierzchni posiadało woj. krakowskie, gminnych zaś - kieleckie. Analiza danych prowadzi do wniosku, że w latach 1935-1938 nie można mówić o wyższej dynamice budowy dróg państwowych niż w latach 1924-1935. Podobnie kwestia ta przedstawiała się w przypadku dróg wojewódzkich, powiatowych i gminnych. W przypadku tych ostatnich zdecydowaną poprawę dynamiki budowy dróg o twardej nawierzchni w latach 1936-1938 w porównaniu z latami 1924-1938 widać jedynie w przypadku woj. lwowskiego i krakowskiego.

Ogólnie stwierdzić można, że przynajmniej do 1938 r. nie było zdecydowanej poprawy w zakresie dynamiki budowy państwowych i samorządowych dróg o twardej nawierzchni na terenie COP. Stosownie do możliwości finansowych starano się jedynie zabezpieczać środki na najbardziej pilne potrzeby. Intensyfikacja budowy dróg samorządowych w poszczególnych obszarach COP była zróżnicowana. Na przykład dla janowskiego związku samorządowego rok budżetowy 1937/1938 był korzystny. Uzyskano bowiem zwyżkę dochodów w wysokości 100 tys. zł. Świadczyło to o lokalnej poprawie gospodarczej. Zwiazek samorządowy miał możliwość zatrudniania średnio 300 robotników przy budowie dróg, a także zapewnienia sobie odpowiednich środków finansowych na materiały budowlane. W sprawozdaniu janowskiego związku samorzadowego na 1937/1938 r. czytamy: „Rozwój inwestycyj drogowych w powiecie, zawdzięczamy, poza wskazaną wyżej okolicznością niezwykle szczęśliwej i pomyślnej okazji włączenia powiatu do Centralnego Okręgu Przemysłowego". Ze sprawozdania wynika również, że pozytywna dla samorządów była budowa dróg państwowych, co było widoczne na przykładzie arterii komunikacyjnej Janów Lubelski - Nisko. W sprawozdaniu sa zawarte informacje, że usprawniona została również budowa dróg powiatowych ${ }^{48}$. Z kolei $\mathrm{w}$ relacji mieszkańca $\mathrm{z}$ okolic pow. jarosławskiego i przeworskiego znajdujemy negatywna ocenę stanu dróg: „Mieszkam na terenie C.O.P.-u - powiat jarosławski i przeworski, na mapie przynajmniej do Copu się zaliczaja, a mieszkam na granicy, prawie, tych dwóch powiatów. Otóż chciałbym pokazać mieszkańcom Warszawy, jakie w tym Centralnym Okręgu Przemysłowym mamy drogi, a właściwie bezdroża. Mamy $16 \mathrm{~km}$ do Jarosławia i tyleż do

${ }^{48}$ AAN, Zwiąek Powiatów RP, t. 291, Sprawozdanie z działalności Janowskiego Wydziału Powiatowego za czas od 22 XII 1937 do 26 VII 1938 r., s. 319-320. 
Przeworska, droga jest taka, że o przejechaniu na resorach o tej porze roku mowy nie ma. Wozem po okropnych dziurach i błocie jedzie się do każdego z tych miast $2 \frac{1}{2}-4$ godzin. Sa [to] stosunki zupełnie nie europejskie i po prostu trudne do wytrzymania dla człowieka XX-go wieku" ${ }^{49}$. Budowa nowych fabryk powodowała, że na drogach znacznie zwiększył się przewóz materiałów budowlanych. Przekładało się to jednocześnie na większy stopień zniszczenia dróg. Uważano zatem, że część środków na naprawę i budowę dróg powinny przeznaczyć fabry$\mathrm{ki}^{50}$. Zapewne $\mathrm{z}$ intensyfikacją budowy dróg na terenie COP mielibyśmy do czynienia gdyby nie wybuch II wojny światowej. Poza tym szerzej kwestia budowy dróg w COP została poruszona w Biurze Planowania Krajowego dopiero w lipcu 1937 r., szczególnie w kontekście wypełnienia pustki komunikacyjnej w punkcie łączącym wszystkie rejony $\mathrm{COP}^{51}$.

Ważna dziedzina $\mathrm{w}$ gospodarczej działalności samorządu terytorialnego na terenie COP była koordynacja szkolnictwa powszechnego. Uważano, że lokalne związki samorządowe mają niewielkie możliwości finansowe w stosunku do rzeczywistych potrzeb rozbudowy szkolnictwa na terenie COP. Tak szkolnictwo powszechne w krakowskiej części COP oceniał Władysław Kabaciński: „Blisko połowa izb szkolnych to izby ciasne o 30-40 metrach kwadratowych powierzchni podłogi. W takich izbach pomieścić trzeba przeważnie 60 uczniów, a jest miejsce na 40"52. Wyrażano konieczność pomocy finansowej państwa $\mathrm{w}$ zakresie szkolnictwa powszechnego $\mathrm{w} \mathrm{COP}^{53}$. Niewielkie sumy na to przeznaczało Towarzystwo Popierania Budowy Szkół Powszechnych, ponieważ system dystrybucji środków tegoż uprzywilejowywał Kresy Wschodnie $^{54}$. 20 I 1938 r. w Rzeszowie w sali magistratu miejskiego odbyła się konferencja poświęcona rozbudowie szkolnictwa na terenie COP. Udział w niej wzięli m.in. przedstawiciele samorządu. W dyskusji poruszono kwestię szkolnictwa powszechnego ${ }^{55}$. W publicystyce prasowej poruszającej problemy gospodarczo-społeczne COP niejednokrotnie poświęcano uwagę temu zagadnieniu. Tadeusz Kutrzeba podał przykład powiatu mieleckiego, w którym stan około 20 budynków szkol-

${ }^{49}$ Z Małopolski środkowej, „Gazeta Rolnicza” 1939, nr 19, s. 467.

${ }^{50}$ J. Przetocki, Problem inwestycji w Centralnym Okręgu Przemystowym, „Przegląd Samorządowy" 1938, nr 9, s. 2.

${ }^{51}$ J. Gołębiowski, Dzieje industrializacji..., s. 238, 240.

${ }^{52}$ W. Kabaciński, dz. cyt., s. 3.

${ }^{53}$ O szkoty powszechne..., s. 6.

${ }^{54}$ W sprawie budowy szkót powszechnych..., s. 7.

${ }_{55}$ Zob. AP w Rzeszowie, Akta Miasta Rzeszowa, sygn. 2527, Sprawozdanie z konferencji w sprawie rozbudowy szkolnictwa na terenie Centralnego Okręgu Przemysłowego, s. 3-14. 
nych oceniano jako niedostateczny, a na 87 szkół powszechnych 80 posiadało swoje budynki, pozostałe zaś je wynajmowały. Publicysta ocenił, że rozpoczęcie inwestycji COP przyspieszyło tempo budowy szkół: podczas gdy w latach poprzedzajacych inwestycje wznoszono średnio jedna szkołę rocznie, to już w okresie dobrej koniunktury wskaźnik ten miał wynosić 2 . Stwierdził, że tempo budowy szkół powszechnych powinno było zwiększyć się do 4 rocznie. Informacja ta ma typowo propagandowy charakter, aczkolwiek autor artykułu podał informację, że w latach 1933-1938 zbudowano 7 szkół. Natomiast w 1938 r. w powiecie mieleckim budowano 5 szkół, a w następnych latach planowano wzniesienie 5 kolejnych. Świadczyć to mogło jednak o faktycznym zwiększeniu tempa budowy ${ }^{56}$. W innym artykule, na temat stanu szkolnictwa w powiecie puławskim, napotykamy informację o rozpoczęciu budowy „17 szkół naraz”. Dowiadujemy się również o korzystnej współpracy samorządu terytorialnego z lokalnym społeczeństwem. Charakterystyczna jest wzmianka o takiej treści: „Sa np. wioski, gdzie rolnicy samorzutnie po 5 zł za morga opodatkowują się byle tylko u nich czy też w sasiedniej wiosce szkoła powstała" ${ }^{57}$. Ponownie mamy do czynienia z informacja o charakterze propagandowym.

Nie można jednak zaprzeczyć, że rozwój gospodarczy miał w pewnym sensie wpływ na uświadomienie sobie przez społeczeństwo i władze lokalne konieczności rozwoju oświaty powszechnej. W przypadku informacji z powiatu puławskiego chodziło najprawdopodobniej o powiększenie funduszu budowy szkół poprzez zwiększenie podatku. Z materiałów archiwalnych wiemy, że w gminie Nałęczów w powiecie puławskim chciano zaplanowano w budżecie na 1938/1939 r. na fundusz budowy szkół większą kwotę, a na pokrycie tego funduszu uchwalić dodatkowo po 25 gr z 1 ha na podatek wyrównawczy ${ }^{58}$. Ludwik Ręgorowicz tak pisał w 1938 r. na temat szkolnictwa powszechnego w rejonie COP: „W zakresie powszechności nauczania i wykonania obowiązu szkolnego cały omawiany teren przedstawia się stosunkowo dobrze. Spośród dzieci w wieku obowiązku szkolnego od 91\% do 95\% wykonuje obowiazzek szkolny. Od 1938/39 roku szkolnego obowiazywać będzie i na tych terenach jednolicie 7-letni obowiazek szkolny, a nie jak było częściowo w okresie przejściowym od 1932/33 do 1937/38 - 6-letni obowiązek szkolny na wsi. Pod względem powszechności

${ }^{56}$ T. Kutrzeba, Rozbudowa szkolnictwa..., s. 10.

${ }^{57}$ Cz.G., Budowa szkót..., s. 3.

${ }^{58}$ AP w Lublinie, Urząd Wojewódzki Lubelski, Wydział Samorządowy, sygn. 48, Wyciag z protokołu 21. posiedzenia Rady Gminnej gminy Nałęczów z 19 I 1938 r., protokół z 20 I 1938 r., s. 5. 
nauczania zatem stosunki $\mathrm{w}$ omawianych powiatach ulegna poprawie" ${ }^{2}$. Aby owo zamierzenie zrealizować, samorządy musiały przeznaczać więcej środków na budowę nowych gmachów szkolnych.

\section{Finansowe aspekty działalności samorządu terytorialnego na terenie COP}

Dla sprawnej organizacji gospodarki samorządowej w II RP potrzebna była odpowiednia koordynacja finansów samorządowych. W okresie Wielkiego Kryzysu w celu zmniejszenia długoterminowego zadłużenia budżetów samorządowych powołano w $1934 \mathrm{r}$. Centralną Komisję Oszczędnościowo-Oddłużeniową. Jej działalność zakończyła się $\mathrm{w} 1937 \mathrm{r} .{ }^{60} \mathrm{~W}$ ramach działalności CKOO działały komisje wojewódzkie, które miały m.in. ustalać plany oddłużenia poszczególnych związków samorządowych. W zakresie akcji oddłużeniowej zadaniem Komisji było m.in. rozpatrywanie planów oddłużenia nieuzgodnionych z wierzycielami i dłużnikami przez komisje wojewódzkie ${ }^{61}$. Wzrost koniunktury gospodarczej po 1936 r. miał przynieść związkom samorządowym poprawę stanu finansów komunalnych ${ }^{62}$.

Kwestia finansów samorządu terytorialnego na terenie COP zostanie przedstawiona na przykładzie budżetów związków powiatowych z centrum COP: sandomierskiego, janowskiego, tarnobrzeskiego, mieleckiego i opatowskiego; związków powiatowych położonych na terenie COP, lecz poza jego centralną częścią: puławskiego i brzeskiego; związków powiatowych leżących poza COP, ale położonych w województwach, w których skład wchodzi COP: włoszczowskiego, wadowickiego, łukowskiego i turczańskiego; a także związków powiatowych leżących w innych częściach II RP: bielsko-podlaskiego i ostrowskiego. Takie zestawienie powiatów jest spowodowane potrzeba, po pierwsze, sprawdzenia struktur budżetów wybranych powiatów w latach budżetowych: 1929/1930 (okres przedkryzysowy), 1933/1934 (szczyt kryzysu), 1935/1936 (depresja pokryzysowa) oraz 1937/1938 (okres dobrej koniunktury), po drugie zaś, odpowiedzi na pytanie, czy w ramach akcji inwestycyjnej budżety związków powiatowych COP faktycznie nastawione były na intensywną działalność

${ }^{59}$ L. Ręgorowicz, Szkolnictwo w Centralnym Okręu Przemystowym na tle powstajacego tam przemystu, „Oświata i Wychowanie” 1938, z. 7, s. 629.

${ }^{60}$ R. Szwed, Samorzqdowa Rzeczpospolita..., s. 48-51.

${ }^{61}$ A.W. Zawadzki, dz. cyt., s. 218-219.

${ }^{62}$ K. Niemski, dz. cyt., s. 26-27. 
inwestycyjną $\mathrm{w}$ porównaniu do budżetów związków powiatowych innych części Polski i czy w centralnej części COP mieliśmy do czynienia $\mathrm{z}$ większym natężeniem gospodarczej działalności samorządu powiatowego. W udzieleniu odpowiedzi na to pytanie pomoże obliczenie stosunku wydatków zwyczajnych do nadzwyczajnych, a także stosunku dochodów zwyczajnych do nadzwyczajnych poszczególnych budżetów powiatowych w kolejnych latach.

Regina Pacanowska wymienia następujacca strukturę budżetu powiatowego II RP: „Zarówno w budżecie administracyjnym, jak i w budżecie zakładów i przedsiębiorstw dochody i wydatki dzieliły się na zwyczajne i nadzwyczajne. Na dochody zwyczajne budżetów składały się: a) przychody z majątku komunalnego; b) czysty zysk z przedsiębiorstw komunalnych; c) wpływy z opłat administracyjnych i z opłat za korzystanie z urządzeń i zakładów komunalnych; d) wpływy z danin komunalnych zaległych $\mathrm{z}$ lat poprzednich oraz przychody z podatków samoistnych i dodatków do podatków państwowych, wpływających do kasy związku z mocy uchwał i statutów komunalnych. Dochody zwyczajne przedsiębiorstw stanowiły wpływy z eksploatacji tych przedsiębiorstw. Do dochodów nadzwyczajnych budżetu administracyjnego zaliczano zaś wpływy ze sprzedaży i likwidacji majątku komunalnego, wpływy z podatków inwestycyjnych, pożyczek długoterminowych oraz wpływy jednorazowe lub przypadkowe. Umieszczano tu również nadwyżki z poprzedniego roku obrachunkowego. Do wydatków nadzwyczajnych miały być zaliczane wydatki niezwiązane z normalnym tokiem administracji lub eksploatacji przedsiębiorstw, a w szczególności wydatki inwestycyjne, czyli wkłady mające dawać stały dochód lub podnieść trwale sprawność gospodarcza, wydatki na nowe budowle, zakup maszyn i nieruchomości. Należały tu także wydatki przeznaczone na przedterminową spłatę zadłużenia długoterminowego (bieżąca obsługa zadłużenia stanowiła wydatek zwyczajny). Wydatki nadzwyczajne mogły być dokonywane tylko wówczas, gdy istniała możliwość ich pokrycia ze środków nadzwyczajnych lub z nadwyżki dochodów zwyczajnych po pokryciu wydatków zwyczajnych. Wydatki zwyczajne nie zostały dokładnie w rozporządzeniu określone, wynikały one jednak z ustawowych obowiązków związków samorządowych" ${ }^{63}$.

W kwestii budżetów samorząów miejskich na terenie COP wiemy, że na wspomnianej konferencji z 17 XII 1938 r. poświęconej miastom z terenu COP Bolesław S. Liszkowski wykazał, że w przypadku

${ }^{63}$ R. Pacanowska, Samorzad powiatowy $w$ Wielkopolsce w latach 1919-1939, Poznań 2006, s. 111. 
finansów tych miast: „zarówno dochody zwyczajne jak i nadzwyczajne miast zmniejszają się, ciężary natomiast stale wzrastaja"64. Tabela 2 ukazuje stosunek wydatków nadzwyczajnych do zwyczajnych oraz stosunek dochodów nadzwyczajnych do zwyczajnych - wybranych budżetów powiatowych związków samorządowych z terenu COP oraz spoza COP w latach 1929/1930-1937/1938. Na podstawie informacji przedstawionych przez Reginę Pacanowską stwierdzić można, że im wyższe są oba stosunki, tym większe są możliwości finansowe samorządu.

Tabela 2. Stosunek wydatków nadzwyczajnych do zwyczajnych oraz stosunek dochodów nadzwyczajnych do zwyczajnych - wybranych budżetów powiatowych związków samorządowych z terenu COP oraz spoza COP w latach 1929/1930-1937/1938

\begin{tabular}{|c|c|c|c|c|c|c|c|c|}
\hline \multirow{3}{*}{$\begin{array}{c}\text { Powiato- } \\
\text { wy zwią- } \\
\text { zek samo- } \\
\text { rządowy }\end{array}$} & \multicolumn{8}{|c|}{ Lata budżetowe } \\
\hline & \multicolumn{2}{|c|}{$1929 / 1930$} & \multicolumn{2}{|c|}{ 1933/1934 } & \multicolumn{2}{|c|}{$1935 / 1936$} & \multicolumn{2}{|c|}{$1937 / 1938$} \\
\hline & 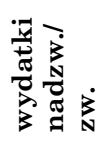 & 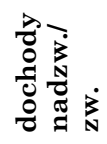 & 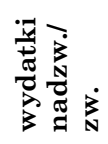 & 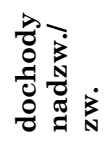 & 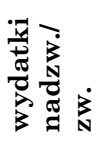 & 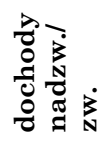 & 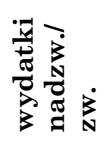 & 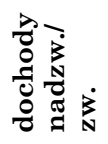 \\
\hline opatowski & 0,501 & 1,216 & 0,285 & 0,320 & 0,210 & 0,133 & 0,240 & 0,107 \\
\hline mielecki & $\begin{array}{c}\text { brak } \\
\text { wyd. } \\
\text { nadzw. }\end{array}$ & $\begin{array}{c}\text { brak } \\
\text { doch. } \\
\text { nadzw. }\end{array}$ & $\begin{array}{c}\text { brak } \\
\text { wyd. } \\
\text { nadzw. }\end{array}$ & $\begin{array}{c}\text { brak } \\
\text { doch. } \\
\text { nadzw. }\end{array}$ & 0,175 & 0,026 & $\begin{array}{c}\text { brak } \\
\text { wyd. } \\
\text { nadzw. }\end{array}$ & 0,115 \\
\hline $\begin{array}{l}\text { sandomier- } \\
\text { ski }\end{array}$ & $\begin{array}{c}\text { brak } \\
\text { danych }\end{array}$ & $\begin{array}{l}\text { brak } \\
\text { danych }\end{array}$ & $\begin{array}{c}\text { brak } \\
\text { danych }\end{array}$ & $\begin{array}{c}\text { brak } \\
\text { danych }\end{array}$ & 0,312 & 0,026 & 0,245 & 0,115 \\
\hline janowski & 0,745 & 0,621 & $\begin{array}{c}0,157 \\
\text { dane za } \\
1934 / \\
1935\end{array}$ & $\begin{array}{c}\text { brak } \\
\text { doch. } \\
\text { nadzw. }\end{array}$ & 0,031 & 0,094 & 0,609 & 0,140 \\
\hline tarnobrzeski & 0,325 & 0,442 & 0,221 & 0,174 & 0,100 & $\begin{array}{c}\text { brak } \\
\text { doch. } \\
\text { nadzw. }\end{array}$ & 0,120 & $\begin{array}{c}\text { brak } \\
\text { doch. } \\
\text { nadzw. }\end{array}$ \\
\hline puławski & 0,362 & 0,184 & 0,095 & $\begin{array}{c}\text { brak } \\
\text { doch. } \\
\text { nadzw. }\end{array}$ & 0,206 & $\begin{array}{c}\text { brak } \\
\text { doch. } \\
\text { nadzw. }\end{array}$ & 0,135 & $\begin{array}{l}\text { brak } \\
\text { doch. } \\
\text { nadzw. }\end{array}$ \\
\hline brzeski & 0,676 & 0,367 & 0,016 & $\begin{array}{c}\text { brak } \\
\text { doch. } \\
\text { nadzw. }\end{array}$ & 0,152 & 0,045 & 0,156 & 0,119 \\
\hline
\end{tabular}

${ }^{64}$ Zjazd przedstawicieli miast..., s. 6.

${ }^{65}$ Obliczenia i opracowanie własne na podstawie: AAN, Związek Powiatów RP, Sprawozdania z bilansów i zamknięć rachunkowych powiatowych związków samorzadowych, pow. bielsko-podlaski: t. 41, 43, 44; pow. opatowski: t. 148, 149, 150; pow. włoszczowski: t. 181; pow. ostrowski: t. 819; pow. puławski: t. 314; pow. brzeski: t. 199; pow. tarnobrzeski: t. 410; pow. wadowicki: t. 257; pow. mielecki: t. 235; pow. łukowski: t. 309; pow. turczański: t. 414; pow. sandomierski: t. 172; pow. janowski: t. 291. 


\begin{tabular}{|c|c|c|c|c|c|c|c|c|}
\hline włoszczowski & 0,991 & 0,466 & 0,314 & $\begin{array}{l}\text { brak } \\
\text { doch. }\end{array}$ & 0,201 & $\begin{array}{l}\text { brak } \\
\text { doch. }\end{array}$ & 0,356 & 0,191 \\
\hline wadowicki & 0,135 & 0,140 & $\begin{array}{c}\text { brak } \\
\text { wyd. } \\
\text { nadzw. }\end{array}$ & $\begin{array}{c}\text { brak } \\
\text { doch. } \\
\text { nadzw. }\end{array}$ & $\begin{array}{c}\text { brak } \\
\text { wyd. } \\
\text { nadzw. }\end{array}$ & $\begin{array}{c}\text { brak } \\
\text { doch. } \\
\text { nadzw. }\end{array}$ & 0,005 & 0,005 \\
\hline łukowski & 0,830 & 1,027 & 0,520 & 0,077 & 0,217 & 0,037 & 0,777 & 0,180 \\
\hline turczański & $\begin{array}{c}\text { brak } \\
\text { wyd. } \\
\text { nadzw. } \\
\text { (dane } \\
\text { za } \\
1930 / \\
1931 \text { ) }\end{array}$ & $\begin{array}{c}\text { brak } \\
\text { doch. } \\
\text { nadzw. } \\
\text { (dane } \\
\text { za } \\
1930 / \\
1931\end{array}$ & $\begin{array}{c}0,143 \\
\text { (dane } \\
\text { za } \\
1933 / \\
1934)\end{array}$ & $\begin{array}{c}0,192 \\
\text { (dane } \\
\text { za } \\
1933 / \\
1934 \text { ) }\end{array}$ & 0,023 & $\begin{array}{c}\text { brak } \\
\text { doch. } \\
\text { nadzw. }\end{array}$ & 0,005 & $\begin{array}{l}\text { brak } \\
\text { doch. } \\
\text { nadzw. }\end{array}$ \\
\hline $\begin{array}{l}\text { bielsko- } \\
\text {-podlaski }\end{array}$ & 0,183 & 0,156 & 0,080 & 0,061 & 0,070 & 0,066 & 0,703 & 0,260 \\
\hline ostrowski & 0,050 & 0,070 & 0,145 & 0,054 & 0,152 & 0,144 & 0,233 & 0,202 \\
\hline
\end{tabular}

$\mathrm{Na}$ podstawie danych zawartych w tabeli 2 można stwierdzić, że budżety niemal wszystkich wymienionych w tabeli związków samorządowych w ogóle bądź wyraźnie nie poprawiły swoich zdolności finansowych $\mathrm{w}$ okresie dobrej koniunktury w porównaniu z okresem przedkryzysowym. Polepszenie widzimy jedynie w przypadku pow. bielsko-podlaskiego i ostrowskiego. Faktem jest, że w 1937/1938 budżety związków powiatowych położonych centralnie na terenie COP, tj. pow. opatowskiego, sandomierskiego i w szczególności janowskiego (oprócz mieleckiego i tarnobrzeskiego) miały wyższy stosunek dochodów nadzwyczajnych do zwyczajnych w porównaniu do powiatów, które leżały na obrzeżach COP. Dwa zaś spośród czterech wymienionych w tabeli powiatów okalajacych COP, tj. łukowski i włoszczowski, miały wyższy stosunek wydatków nadzwyczajnych do zwyczajnych od budżetów związków powiatowych leżących centralnie na terenie COP, oprócz sandomierskiego. Stosunek wyższy od budżetu pow. sandomierskiego miał jedynie pow. łukowski. Natomiast w przypadku powiatów leżących w innych częściach II RP budżet pow. bielsko-podlaskiego miał wyższy stosunek od wszystkich wymienionych $\mathrm{w}$ tabeli budżetów powiatów położonych centralnie na terenie COP. Stosunek dotyczący wydatków w przypadku budżetu pow. ostrowskiego w 1937/1938 r. znajdował się na poziomie tychże stosunków w przypadku budżetów powiatów położonych centralnie na terenie COP.

Na podstawie analizy stwierdzić można, że powiaty COP położone jedynie w jego centralnej części mogły odznaczać się zwiększoną aktywnością budżetów samorządowych w okresie inwestycji. Okres poprawy gospodarczej 1936-1939 dotyczył zatem na równi samorządów 
w całym kraju. Budżety wszystkich związków samorządowych położonych w centrum i na obrzeżach COP (poza puławskim i tarnobrzeskim, które dochodów nadzwyczajnych nie miały) pod względem stosunku dochodów nadzwyczajnych do zwyczajnych stały na podobnym poziomie. Spośród powiatów okalających COP jedynie włoszczowski i łukowski miały omawiany stosunek na podobnym poziomie co powiaty wchodzace w skład COP. Niższy poziom od tych ostatnich miały pow. wadowicki i turczański. Natomiast wyższy stosunek dochodów nadzwyczajnych od zwyczajnych w 1937/1938 r. od budżetów wszystkich powiatów COP miał zarówno pow. bielsko-podlaski, jak i ostrowski.

Analiza stosunku dotyczącego dochodów podkreśla jeszcze, że poprawa gospodarki samorządowej w okresie 1936-1939 dotyczyła w podobnej mierze całego kraju. Na terenie COP nie nastapiła taka poprawa, która wyróżniałaby się pod względem stanu finansów komunalnych na tle reszty kraju. Pewne różnice można zaobserwować jedynie w obrębie samego COP pod względem wydatków nadzwyczajnych. Większa intensyfikacja inwestycji samorządowych faktycznie miała miejsce w powiatach centralnej części COP w porównaniu do powiatów reszty okręgu przemysłowego. Nie oznacza to jednak, że decyzja o koncentracji przemysłu w dorzeczach Wisły i Sanu nie zaabsorbowała lokalnych samorządów specyficznie na tle całego kraju. Co ciekawe, ulgi inwestycyjne wprowadzone na terenie COP ustawa z 9 IV 1938 r. ${ }^{66}$ po części negatywnie wpływały na lokalne finanse samorządowe. Na konferencji poświęconej podziałowi administracyjnemu na obszarze COP, odbytej 7 XI 1938 r. w MSW, dyrektor Departamentu Samorządu przy MSW Stanisław Podwiński wypowiedział następujace słowa: „Raptowny ruch inwestycyjny w C.O.P. powoduje ruinę samorządu, gdy wskutek ulg inwestycyjnych nowopowstałe przedsiębiorstwa prawie nic nie płaca i powodują b[ardzo] znaczne zwiększenie wydatków samorządu (drogi, szkoły, opieka społ[eczna], zdrowie), na co brak zupełny środków. Należy tą sprawą poważnie się zająć" ${ }^{67}$. Aleksander Ivánka pisał we wspomnieniach, że inwestycje COP spowodowały wzrost bieżących wydatków lokalnych związków samorządowych, a także wzrost potrzeb inwestycyjnych. „Na 47 miast, położonych na tym obszarze, co do których

${ }^{66}$ Zob. Ustawa z dnia 9 kwietnia 1938 r. (Dz. U. R. P. Nr. 26, poz. 224), o ulgach inwestycyjnych. Rozdziat I. Ulgi w Centralnym Okregu Przemysłowym, w: Ulgi inwestycyjne. Rozporzadzenie wykonawcze. Biblioteka teksów ustaw 33, Kraków 1939; Z. Klarner, Ulgi Przemystowe w COP, Warszawa 1939.

${ }^{67}$ CAW, Oddział I Sztabu Generalnego, sygn. I.303.3.799, Protokół konferencji odbytej 7 XI 1938 r. w Ministerstwie Spraw Wewnętrznych w sprawie podziału administracyjnego na obszarze Centralnego Okręgu Przemysłowego, s. 287. 
Związek Miast przeprowadził ankietę, 27 groziło zamknięcie budżetu 1938/39 deficytem. Na pokrycie inwestycji w tymże 1938/39 r. w kwocie $8 \mathrm{mln}$ zl, otrzymało owe 47 miast w formie dotacji i pożyczek $4,5 \mathrm{mln}$ zł. Na $22 / 7 \mathrm{mln}$ zł kosztów inwestycji projektowanych na 1939/40 r., posiadały miasta środków własnych na sumę niespełna $2 \mathrm{mln}$ zł. Groziło powtórzenie się historii Gdyni z okresu budowy por$t^{\prime \prime 68}$. Dokładne omówienie kwestii funkcjonowania finansów samorzadowych na terenie COP wymaga niewątpliwie podjęcia szerszych badań.

$$
* * *
$$

Zapewne przedstawienie powyżej jedynie w pewnym wycinku gospodarczo-finansowych aspektów funkcjonowania samorządu terytorialnego na terenie COP nie wyczerpuje w pełni poruszonego w artykule problemu. W kwestiach gospodarczych należałoby przedstawić przede wszystkim jeszcze takie dziedziny funkcjonowania samorządu terytorialnego na terenie COP jak: publiczna służba zdrowia, szeroko pojęta infrastruktura miejska, wpływ rozwoju sektora prywatnego na samorząd terytorialny, kwestie jego współpracy z sektorem spółdzielczym, samorządem gospodarczym, zrzeszeniami zawodowymi, przemysłowymi i rolnymi, realizacja inwestycji rolnych i wspieranie rolnictwa, szarwark, polityka gruntowa itd. W kwestiach finansowych niezbędne wydaje się dokładne zbadanie struktur budżetów samorządowych pod względem zadłużenia krótko- i długoterminowego, przedstawienie problematyki kredytu z Komunalnego Funduszu Pożyczkowo-Zapomogowego, zbadanie funkcjonowania Komunalnych Kas Oszczędności i dokładniejsza analiza tzw. budżetów specjalnych.

$\mathrm{Na}$ podstawie przedstawionych $\mathrm{w}$ artykule informacji stwierdzić można z dużą dozą pewności, że związki samorządowe położone na terenie COP, w szczególności w jego centralnej części, z przyczyn naturalnych musiały zwiększyć swoje nakłady finansowe na inwestycje. Wpływ na to miały dynamiczne inwestycje przemysłowe, które aby były rentowne i opłacalne, musiały rozwijać się równolegle z innymi obszarami lokalnego życia gospodarczego. Zlokalizowana wokół byłej granicy zaborów pustka w infrastrukturze gospodarczo-społecznej musiała być usunięta, aby nowy okręg przemysłowy mógł funkcjonować sprawnie. Inną kwestię stanowiły już problemy finansów samorządowych. Często związki samorządowe z powodu tych właśnie problemów nie mogły wypełniać swoich obowiązków. Bardzo często było to obowiązki

${ }^{68}$ A. Ivánka, Wspomnienia skarbowca, Warszawa 1964, s. 239. 
nie kreowane przez sam samorząd, ale nałożone przez instytucję państwową. Dlatego wydaje się, że na terenie COP już po wprowadzeniu nowej ustawy samorządowej z 1933 r., kiedy zmniejszyła się autonomia samorządu terytorialnego w Polsce, lokalne związki samorządowe doznały swoistego rozdwojenia. Oczywiste ograniczenia w możliwościach finansowych były nie do pogodzenia z narzuconymi przez państwo obowiązkami. Pewną forma pomocy miało być przyznawanie kredytu z Komunalnego Funduszu Pożyczkowo-Zapomogowego. Wyższy stopień wsparcia finansowego Polskiego Banku Komunalnego miał dotyczyć m.in. terytoriów COP. W protokole z posiedzenia specjalnej komisji Komunalnego Funduszu Pożyczkowo-Zapomogowego z 25 I 1939 r. zawarta były bowiem następująca ważna informacja: „Pożyczki według kolejności udzielone będą na 1) pokrycie wydatków wywołanych finansowaniem robót publicznych przez inne instytucje, 2) pokrycie niedoborów spowodowanych wypadkami specjalnej natury (szczególnie okoliczności, wynikłe w ciagu roku budżetowego), 3) konieczne remonty, 4) nieodzowne inwestycje $\mathrm{w}$ zasadzie nie rentujace się, 5) pomiary i plany, 6) zasilenie funduszów kasowych dla terminowego wykonania budżetu w razie niemożności uzyskania kredytu z innych źródeł. Komisja przed początkiem każdego roku budżetowego ustali dla siebie orientacyjnie, jaka suma przeznaczona będzie w przybliżeniu na każdy z wymienionych celów, przy czym jeśli chodzi o pożyczki na inwestycje nie rentujące się - przeznaczona będzie na nie suma około $40 \%$ ogólnej sumy wpływów na fundusz pożyczkowy. Przyznawanie pożyczek na inwestycje będzie się odbywało przy zachowaniu zasad: a) silniejszego uwzględnienia podań o pożyczki związków samorządowych, znajdujących się na terenach kresowych, bądź pogranicznych i C.O.P., b) ustalenie sum przybliżonych na grupy województw, celem zorientowania województw o możliwościach kredytowych w tym zakresie w danym roku budżetowym"69.

Związi samorządowe działające na terenie COP niewątpliwie stanowiły bardzo ważne instytucje z punktu widzenia społecznego, choćby z powodu konieczności zapewnienia bezpieczeństwa publicznego i organizacji kredytu komunalnego. Dlatego gospodarczo-finansowe aspekty działalności samorządu terytorialnego na terenie COP w dalszych badaniach będą musiały być niewątpliwie poszerzone o kwestie społeczne.

${ }^{69}$ AAN, Polski Bank Komunalny, t. 16, Wyciąg z protokołu posiedzenia specjalnej komisji Komunalnego Funduszu Pożyczkowo-Zapomogowego z 25 I 1939 r., s. 42. 
Wojciech Chudzik

Economic-financial Aspects of the Functioning of the Territorial Self-government with the Central Industrial Region Investments (1936-1939)

(Summary)

The purpose of this article is to demonstrate the impact exerted by the investments of the Central Industrial Region upon the local administration. The source survey conducted by the author proves that the creation of a new industrial region was connected with an extremely wide gamut of problems relating to local socio-economic life. The key issue was to adapt the economic structure to the developing industry. Exceptional responsibility for this task was entrusted to particular rungs of territorial self-government. An intensification of the activity pursued by state investments forced self-government unions to increase liability for all socio-economic issues in the region and hence to enlarge the expenses borne by local budgets. The presented reflections show upon the example of selected domains of the local economy the degree to which the activity of self-government unions grew in the Central Economic Region. Next, the author went on to analyse the functioning of self-government finances using the example of the budgets of particular county communal unions in order to illustrate the actual efforts made by the self-government administration as part of support for the socio-economic modernisation of the central and southern territories of the Second Republic of Poland.

Wojciech Chudzik - Instytut Historii Uniwersytetu Marii Curie-Skłodowskiej w Lublinie; e-mail: voidt22@wp.pl 